\title{
CHARTING A NEW DIRECTION AND STRATEGY IN NEPAL'S FOREIGN POLICY
}

- Dr. Nischal Nath Pandey

\begin{abstract}
Despite assorted contributions to the understanding of how Nepal's foreign policies are formulated, and how different actors and factors shape and implement them, foreign policy research remains largely centered in the Ministry of Foreign Affairs. But it doesn't mean that the increasing importance of other actors can be ignored. Thus, this paper aims to discuss a dire need to revamp our institutional structures regarding foreign policy decision-making and implementation to suit the new challenges and opportunities that have come on the way because of changes and transformation in the global and national politics. This research identifies the growing number of actors in foreign policy decision-making and implementation along with the changing geopolitical and geo-economic scenario of Nepal, and concurrently reiterates that Nepal must comprehensively overview the efficacy of other ministries and departments that influence foreign policy making and implementation to bring into synergy. Hypothesising that Nepal's foreign engagement can be robust with policy coordination and structural change, the paper gives a way forward to improve and adapt to the changes, and chart a new direction for Nepal's foreign relations.
\end{abstract}

Keywords: Foreign Policy, Actors, Policy Coordination, Structural Change,

\section{Introduction}

Every state aims to formulate long-term and short-term goals, chiefly to capitalise on the benefits it can gain from the established system. Only through an efficient foreign policy and effective implementation of the policy through diplomacy can a state preserve its sovereignty, territorial integrity and promote the national interest. Essentially, for small powers like Nepal, although there are limited foreign policy a choice regarding international politics, Nepal has perpetually endeavoured to optimise national interest through foreign policy implementation and international engagements (Baral, 2018). Similarly, increase in the actors, either state or non-state (international, intergovernmental, private and transnational), in global politics has consequences for foreign policy theory and practice (Stengel \& Baumann, 2017). Because

He is Director of Centre for South Asian Studies (CSAS), and convener of Consortium of South Asian Think-Tanks (COSATT). He was Executive Director of the Institute of Foreign Affairs (IFA) and also advisor to the National Planning Commission. 
of the increased number of actors and platforms in foreign policy decisionmaking, systematic approaches like neorealism and constructivism have difficulties in adapting to the realities of foreign policy. Even the growing interdependence among the states due to globalisation and the structural and institutional changes as a bi-product of these varying aspects have added actors within the state and in the international environment (Stares, Jia, Tocci, Jaishankar, \& Kortunov, 2020). For Nepal and its international engagements, foreign policy actors previously were solely the executive heads, the king or the prime ministers of the country. They used to practise foreign policy and diplomacy through several institutional structures, which adapted to the changing dynamics in different periods. Retrospectively, Nepal's international engagement was limited to Tibet and British India before 1816, but after the consequences of the Anglo-Nepal War (1814-1816), Nepal's international relations paradigm was limited to British India and Britain, which became more prominent during the Rana regime. Only after the introduction of democracy in Nepal in 1951, the foreign relations of Nepal became robust and expanded in the latter days (Joshi \& Rose, 2004).

In the latter decades, Nepal has gone through several changes and transitions. Similarly, the international system has also gone through several systematic modifications. The traditional diplomatic practices have gone through alterations, and the actors in foreign policy decision-making have substantially surged up. Now, the question arises: with the increase in the number of actors and also Nepal's international engagements, has Nepal structurally transformed and coordinated its policies with these changes?

The best way to answer this question is to engage with the works of literature related to Nepal's foreign policy, its geopolitical importance and the changing nature of foreign policy and diplomacy. This work concentrates specifically on those issues that Nepal's foreign policy research has ignored, namely with the increase in the state actors as a result of changes in domestic and international politics. Thus, the study aims to identify the increasing number of actors in foreign policy decision-making and implementation and provide recommendations on policy coordination and structural change to cope with these changes.

\section{Methodology}

The paper attempts to make a critical analysis of Nepal's foreign policy, diplomacy, institutional structure and regional and international engagements. The paper has also made a retrospective and diachronic analysis of international affairs and Nepal's engagement in those affairs. The paper is 
based on information collected, especially through secondary data, like books and journals related to Nepal's foreign policy by prominent academicians, diplomats and analysts. The comparative, evaluative and analytical methods for the study have included ideas, assumptions and analysis for the structural reforms and policy coordination recommendations.

\section{New Actors in Foreign Policy Decision-making of Nepal}

Nepal's foreign affairs and international relations are one of the oldest in the world. From Jaisi Kotha to the Ministry of Foreign Affairs, Nepal developed and modified several institutional structures for international engagements. In Nepal, before the political changes in 1951, there were no provisions for the establishment of the Ministry of Foreign Affairs (MoFA). Also, Nepal's foreign relations were very limited. But the newly introduced democratic system brought a different foreign policy outlook. During the Panchayat era, Nepal's foreign relations and international engagements increased, and Nepal adopted different foreign policies to adapt itself to the international order at that time (Bhattarai, 2019). After the end of the Cold War, the world went through tremendous globalisation and economic liberalisation. The power relationships, the world system and strategic rivalry among the states changed. Issues such as migration, climate change, resource scarcity, transnational terrorism and nuclear proliferations took prominence. In the same period, Nepal also went through the changes (Stares, Jia, Tocci, Jaishankar, \& Kortunov, 2020). After 1990 , and particularly after the declaration of multi-party democracy in Nepal, the Nepali economy also got liberalised. The Maoist movement flagged the way to uplift the marginalised people's voices and reinforce the social movement for change during the period 1996-2006, which also affected the development of the state, and people migrated to other countries for work and settlements (Hamal, 2002). In 2015, the Constitution of Nepal was promulgated with the principles of republicanism, federalism, secularism and inclusiveness. In this context, China's rise and India as an emerging economy in Asia enhanced the geopolitical importance of Nepal more than ever (Baral, 2018). Thus, this phase can be characterised by growing geopolitical and geo-economic competition with increased developmental assistance and strategic partnerships.

Moreover, the increased engagement of external actors and the changed scenario in Nepal also led different government authorities other than MoFA to involve themselves in external relations. Not only MoFA, other government authorities like the Ministry of Finance, National Planning Commission, Ministry of Labour, Employment and Social Security, Ministry of Culture, Tourism and Civil Aviation, Nepal Tourism Board and others have engaged 
actively with foreign actors (Adhikari, 2015). This growing multidimensional engagement in Nepal correspondingly led to structural scarcity to deal with these changing circumstances and an absence of coordination among the existing institutions. It has been reported time and again that the "Economic Cooperation Coordination Division" under the Ministry of Finance, for instance, negotiates and signs agreements with foreign governments without thorough consultation with MoFA, at times, resulting in controversies. The National Security Council Secretariat could be referred more regularly on matters relating to national security and dealings with specific countries. The Ministry of Culture, Tourism and Civil Aviation along with the Nepal Tourism Board, the Ministry of Labour, Employment and Social Security, Ministry of Home and Ministry of Defense are key ministries that see a steady flow of dealings with foreign countries and embassies based in Kathmandu.

Provinces have lately emerged as other important components of our overall foreign policy discussion. The Constitution of Nepal has provided for the mobilisation of foreign aid and grants with the consent from the centre under the jurisdiction of the provinces (Constitution of Nepal, 2015), which makes them new actors in foreign development aid politics. The significant involvement of different ministries as well as local level bodies means more cumbersome foreign policy decision-making in the years ahead. Therefore, there is a need to see the whole gamut of our international relations exercise in its entirety. All in all, "foreign policy is made in the name of the state, but it is the government which formulates and executes it. The government is not an inanimate body. It is a synthesis of organisations and individuals having their organisational and personal interests which are not necessarily similar" (Malhotra, 1993, p. 199). Therefore, when one talks about foreign policy decision-making, it is essential to take into consideration the new actors and factors in shaping Nepal's foreign relations.

\section{International Practices}

Amid the complex web of structural interdependencies in foreign policy decision-making and practices, a question is posed: what are the key actors and factors that influence decision-making on issues related to security and foreign policy, and which institution ensures that all branches of the state abide by the constitutional provisions on foreign policy matters? These issues are perpetually debated in the parliamentary committees, media and among public intellectuals.

While it is up to the government to select the foreign policy experts to advise the prime minister and the foreign minister on issues related to foreign affairs, 
the institutional arrangement of the government needs to be fortified in such a way that the basic contours of foreign policy are always adhered to. The institutional advice to the head of the government must always be paramount as this is what has been practised in other countries, including neighbouring India, which also adopts a parliamentary system of democracy. The Ministry of External Affairs (MEA) in India overrides decisions on foreign policy to such an extent that foreign visits of even powerful chief ministers of big states have been cancelled due to failure in receiving concurrence from the MEA (Dutta, 2001). Although the Nepal government has framed a regulation for all top leaders of the country to inform MoFA before meeting any foreign dignitary, unfortunately, as reported, it is flouted by the same people that brought the regulation to implementation (Bhattarai, 2018).

Another crucial body that has come to play a pivotal role in shaping Nepal's foreign relations is the Parliamentary Committee on International Relations. Comprising members of the parliament, this committee often directs the government on crucial foreign policy cruxes, such as on border issues but at times thwarting foreign film festivals. The legislature's vital position on foreign affairs was also realised by the Constitution of the Kingdom of Nepal-1990, which mandated a two-thirds majority for any treaty signed with a foreign nation (Constitution of Kingdom of Nepal, 1990). The current constitution also mandates a parliamentary hearing of ambassadors before they are officially appointed by the head of state, a feature not practised in established democracies like India and the UK.

With all these actors ranging from the Ministry of Finance to the legislature, there is undoubtedly a clamouring need for weekly coordination meetings among the stakeholders and especially between the ministries of Foreign, Finance, Defense, Home and Labour on foreign policy issues. Weekly National Security Council meetings need to be presided over by the head of the government or a senior deputy prime minister as well, information collated and carefully analysed, and feedback given to MoFA for processing. The significant involvement of so many ministries as well as state and local governments has meant more complicated foreign policy decision-making.

\section{Emerging India and Rising China: Way Forward for Nepal}

Notwithstanding the incumbent deficiencies, we need to comprehend the fact that the exercise of Nepal's international relations is fairly old in comparison to other South Asian states. Nepal established diplomatic relations with the UK before India, Pakistan, Bangladesh, Sri Lanka and the Maldives (Bhattarai, 2019). The bedrock of any foreign policy is to serve national interest, and 
those interests are outlined in the constitution of the day. Most of the salient tenets of Nepal's foreign policy have remained unchanged despite change in regimes, constitutions and governments. But some critical issues seek urgent attention from policymakers and practitioners since the operating environment has changed drastically for our country. We have to answer crucial questions such as: What is our place in the world today? What is our place in the South Asian region? How are we perceived by the international community?

We see the world changing rapidly and with it the global power dynamics. Nepal needs to carefully gauge and analyse the repercussions of this changing world order. Experts have been predicting lately that the rise of India and China will eventually lead to an Asian century. Since the 90s, Asia's gross domestic product has more than tripled, China's GDP has even grown nine-fold. This boom has lifted millions out of poverty and enabled them to join the middle class (Heinl, 2018, p. 110). By 2050, the Chinese economy could be almost 50 per cent larger than its US counterpart, while the Indian economy may follow in the footprints and surpass America a few years later. Nepal needs to equip its missions in India and China, and the consulates in Lhasa and Kolkata, with the necessary manpower, budget and mandate to match this trend so that we can reap benefits from an emerging India and rising China. Universities in these countries need to have Nepal Study Centres (Times of India, 2012). There are currently no Nepal Study Centres in India solely devoted to the study and research on Nepal. The sole centre at Benaras Hindu University (BHU) has now changed its name to 'Nepal and Japan Study Centre'. A collaborative trilateral initiative at the level of think tanks can also be launched by the Institute of Foreign Affairs (IFA). There used to be an 'India Chair' at the Tribhuvan University till a few years back but has been discontinued now. A 'Nepal Chair' needs to be established at a prominent Indian and Chinese university. Fostering contacts between academic institutions and think tanks is crucial for building trust and understanding.

There is no doubt that regional cooperative endeavours, whether at the level of the South Asian Association for Regional Cooperation (SAARC), the Bay of Bengal Initiative for Multi-Sectoral Technical and Economic Cooperation (BIMSTEC), Association of Southeast Asian Nations (ASEAN) and Shanghai Cooperation Organization (SCO), will follow the shift in the global balance of power (Heinl, 2018). As a country located between these two Asian giants, the role of Nepal is instrumental in creating an atmosphere of harmony, peace and cooperation. But the truncated nature of politics in Nepal with typical power asymmetry between Nepal-India and Nepal-China is reinforced by the 
conundrum that if we build strong relations with China, it adversely impacts Indo-Nepal relations and vice versa. Every regime in Kathmandu ever since the unification of the country has had to endure this challenge (KC \& Bhattarai, 2018). "The current transition in Asia is rooted in the gains states have made by actively engaging in cooperation. Cooperative security is not a theory in international relations. It is a process born out of the need to change the domestic and external strategies of states in a new international environment. To sustain the process, Asian states, however, would need to transform what has so far been an ad hoc process into concrete institutions" (Dutta, 2001, p. 347).

The optimum level of equilibrium for us, therefore, is a scenario in which IndoNepal and Sino-Nepal synergy are best utilised in terms of economic benefit for Nepal in terms of trade, tourism, transit, investment and connectivity. This should happen without impinging on our conduct of an independent foreign policy. The traditional notion of "a yam between two boulders" has metamorphosed into a "transit state" or Nepal emerging as "a vibrant bridge" between two Asian giants (KC \& Bhattarai, 2018). In essence, all notions are the same. If trilateral relationship and collaboration between Japan, China and India working together to the advantage of infrastructure opportunities is a possibility, why not trilateral cooperation between China, India and Nepal? (Chaudhary, 2014)

For such a fruitful cooperative endeavour to emerge in the South Asian landscape there needs to be coherence in foreign policy behaviour and a broad understanding between India and China in their policies towards Bangladesh, Nepal, Sri Lanka and the Maldives - the small states in South Asia. The Wuhan and Mamallapuram Summits between Chinese President Xi Jinping and Indian Prime Minister Narendra Modi signalled that their strategic communication has gotten stronger and deeper. Nepal needs to take these new realities into account and study carefully how we can reap benefits from increasing friendliness between our two giant neighbours.

Nepal is currently the Chair of SAARC. It's our singular duty to ensure SAARC meetings are held regularly, and the decisions of the $18^{\text {th }}$ Summit are implemented without hesitation. Member states have come to realise that there is no alternative to SAARC as validated by the teleconferencing during the COVID-19 pandemic among heads of governments of South Asia. Sooner or later, the $19^{\text {th }}$ Summit will be held, but the larger malaise affecting the SAARC process is Indo-Pak rivalry. A weak and powerless Secretariat, lack of sufficient political will, cumbersome decision-making process, and 
provision of unanimity among all members and a non-committal culture of the bureaucracy when Summits are not held on time shouldn't further paralyse the regional entity. As the largest economy in the region, India has a disproportionate responsibility to ensure that this regional project succeeds. As the largest country in the region, its choices and actions will condition the policies of its neighbours and of non-aligned powers that have a stake in the sub-continent (Bajpai, 2013, p. 83). On our part, MoFA of Nepal must act as a guardian of the SAARC Secretariat and the Nepali foreign minister and the foreign secretary must regularly inspect the Secretariat because other member states are not in a position to do so.

\section{Structural Reform and Policy Coordination}

Since the international landscape has changed, so should the world of a Nepali diplomat. This calls for major adjustments inside MoFA. Apart from the internal meetings, there must also be a regular system of consultation among the major political party leaders on foreign policy issues and between the foreign minister and foreign policy experts. These meetings may or may not be publicised. Currently, we see that only during high-level visits to and from the country are such meetings held (Rana \& Chaterjee, 2011).

However, we must also comprehend the fact that the government cannot reenergise our international relations exercise amidst the glaring challenges that confront us both internationally and regionally without adequate human resources and sufficient budget. On both these counts, MoFA is dependent on the other arms of the government. It is here that serious intervention is needed by the head of the government (Dahal, Sainju, Lohani, Sharma, \& Parajuli, 2008). Officials, both gazetted and non-gazetted, are on the front line of MoFA in executing the policies of the Nepal government. They must stay at least three years in the ministry in Kathmandu before being posted outside. This is important. Their in-service training and operating manuals must be accustomed to the changing times. When MoFA sends its officials abroad, more often than they have been assigned to serve different divisions inside the ministry, it creates a skewed organisational structure that breeds inefficiency. In today's age of information revolution, there must be a significant number of staff in the Division to collate and analyse all the information that is coming in from the various missions abroad. Coordination among the line ministries and between MoFA and its missions has always been a major challenge in our context. It can be corrected by conducting regular virtual meetings from within MoFA. Use of new technology will also help reduce unnecessary costs (Bhattarai, 2018).

While the approximate ratio of political appointees and career ambassadors has now been a set practice, we could have a selection committee to be set up by the cabinet for the appointment of ambassadors similar to committees 
it sets up to appoint the vice-chancellors of various universities and lately the governor of Nepal Rastra Bank. The foreign minister can be the chair of this committee, with the selection done from within a roaster developed by the committee, which must be made public.

Another essential element of the restructuring project is the setting up of a "Public Diplomacy Division" inside MoFA headed by a senior joint secretary and support staff. It can also be the same joint secretary who is the spokesperson. Several factors have necessitated the establishment of this new division (Bhattarai, 2018). Firstly, the increasing influence of non-state actors, pressure of NGOs, regular conference reports brought out by various national and international think tanks and the role played by the media have compelled the adoption of a new mindset on the part of the executioners. There is nowadays massive "domestication" of foreign policy. Nepali migrant labour directly complains to the foreign minister or foreign secretary via social media regarding passport and consular matters; tourists bluntly notify about various difficulties being faced at the embassies; investors urgently require information on pending paperwork; TV channels at times telecast live from the border on encroachment, etc. (Ministry of Labour, Employment and Social Security, 2020). Without proper verification, people resort to trolls and comments. A few days later, a small rumour turns into a big political controversy, impacting bilateral relations. States have always tended to evolve the right mix of strategies to deal with different elements of internal politics in other countries that impact them.

Foreign embassies in Kathmandu have long used editorials, newspaper articles and radio programmes as well as visits of journalists to promote their own countries and build a positive image in Nepal. It is high time we also used public diplomacy abroad to try and influence public opinion about our country. With the cooperation of the Nepal Tourism Board (NTB) and Investment Board of Nepal, this Public Diplomacy Division will invite foreign journalists and columnists to promote Nepal and inform/influence the international audience (Dahal R. K., 2018). Since a coherent foreign policy can flow from clearly defined objectives on the domestic front, it is to promote the inherent strengths of a country that a government should follow a certain policy in the external sphere. Therefore, the outreach and dissemination exercise should not only be seen as a PR initiative of the government but more so as an imperative of the changing times in which public perception matters. The planned "Sagarmatha Sambad"(now postponed due to COVID-19 Pandemic), therefore, is another illustration of the outreach that we would like to accomplish to put our views across to the wider international community. We should not forget that the core of the concept of foreign policy [has become] an instrument in the hands of the national states to change the behaviour of other states to their advantage. Ensuring cyber security is a major concern of all countries in the contemporary world. This issue has 
turned out to be another difficulty for all governments around the world. Not so long ago, many countries did not even hold national views on cyber security questions. It means the current and future discussions on international security cyber issues will become more complex and require more time (Heinl, 2018). MoFA, and for that matter, all organs of the Nepal Government must ensure that its communication with missions abroad and within itself is safe and secure. Cyber security is not only the protection of office computers, including hardware, software and data, from cyber attacks but also protecting and making secure the mobile phones and mobile applications of Nepali diplomats and their families. The goal of cyber security is to limit the risks and protect IT assets from the attackers with malicious intent. A separate section can be dedicated as an IT cell devoted to cyber security (Bhattarai, 2018).

\section{Conclusion}

Foreign policy is an instrument for promoting national interest and policy by a state while dealing with the international community. Modern foreign policy and diplomacy are presently experiencing fundamental changes at an unprecedented rate, which have ultimately affected the traditional way of diplomacy and decision- making. These changes are induced by the changes in global politics and international world order. Along with these changes, the actors involved in the formulation and implementation of foreign policy and diplomacy have increased. Not only non-state actors, actors within the state authority have surged up with a growth in the number of foreign and diplomatic engagements. Owing to the same understanding, this study has found that such changes have perceptively impacted foreign policy decision-making. Other than MoFA, other line ministries and government agencies have become a part of international engagements, making them a prominent stakeholder in foreign policy and diplomacy.

These changes pose several challenges to Nepal's foreign policy behaviour. One of the most prominent challenges is the lack of coordination among the actors involved along with the need for structural and institutional changes. Not only have the actors in international relations changed, but also the nature of international cooperation.Most importantly, the geopolitical and geoeconomics interests of Nepal have increased with the rise of India and India. Consequently, these challenges and circumstances urge the policymakers to instantaneously induce policy coordination and structural changes to meet the challenges in the future. Therefore, assessing the strengths and weaknesses of the existing system, analysing the contemporary international political system and also gauging the structural capacity of other states, Nepal can drive a robust foreign policy with a strong institution and institutional collaboration. 
Among them, policy coordination among the line ministries, structural reforms in MoFA, augmentation of the skills of human resources and the use of information and communication technologies are essential for charting a new direction and strategy for Nepal's foreign relations and diplomacy.

\section{References}

Adhikari, R. R. (Ed.). (2015). Promoting Nepalese Trade and Investment Relations with India and China. Kathmandu: Ministry of Foreign Affairs and the Institute of Foreign Affairs.

Aryal, B. (2018). A Study of Foreign Aid Mobilization in Nepal. Kathmandu: Ministry of Foreign Affairs.

Bajpai, K. (2013). India’s Strategic Culture. In K. Bajpai, \& H. Pant (Eds.), India’s Foreign Policy. New Delhi: Oxford Publishing Press.

Baral, B. N. (2018). Changing Dynamics of Nepalese Foreign Policy: Patterns and Trends. Journal of Political Science, XVIII, 25-46.

Bhattarai, M. K. (2018). Recent Trends in Nepal's Foreign Policy, and Role and Functions of Our Diplomats. Journal of APF Command and Staff College, 76-81.

Bhattarai, M. K. (2019). परराष्ट्रका पात्र. Kathmandu: Kitab Publishers Pvt. Ltd.

Chaudhary, B. (2014). Realizing the Vision of a South Asia Union. Kathmandu: COSATTKAS.

Constitution of Kingdom of Nepal. (1990). Constitution of Kingdom of Nepal-1990. Kathmandu: His Majesty's Government.

Constitution of Nepal. (2015). Constitution of Nepal. Kathmandu: Constitution Assembly Secretariat.

Dahal, M. K., Sainju, M. M., Lohani, M. P., Sharma, S. P., \& Parajuli, U. (2008). A Generic Guideline for Development through Economic Diplomacy. Institute of Foreign Affairs.

Dahal, R. K. (2018). The need for Change in Contemporary Nepalese Foreign Policy. Journal of Political Science, XVIII, 82-113.

Dutta, S. (2001). Transition to Cooperative Peace. In J. Singh (Ed.), Reshaping Asian Century. New Delhi: IDSA.

Gujral, I. K. (1998). A Foreign Policy For India. New Delhi, India: Ministry of External Affairs.

Hamal, Y. B. (2002). Ecology of Nepal's Foreign Policy. Kathmandu: Nepal Centre for Development and Policy Studies.

Heinl, C. (2018). Asia Pacific's Contributions to International Cyber Stabilty. Singapore: Panorama, Konard Adenauer Stiftung.

Joshi, B. L., \& Rose, L. E. (2004 [1966]). Democratic Innovations in Nepal: A Case Study of Political Acculturation. Kathmandu: Mandala Book Point.

KC, K., \& Bhattarai, G. (2018, July). Nepal's Search for Prosperity Through Transit Diplomacy. Journal of International Affairs, II(1).

Khanal, Y. N. (2000). Nepal's Non-Isolationist Foreign Policy (1st ed.). Kathmandu, Nepal: 
90 Institute of Foreign Affairs, Nepal : Journal of Foreign Affairs, Vol. 1, No. 1, Jan 2021

Satyal Publication.

Kharat, R. S. (2005). Foreign Policy of Bhutan. New Delhi: Manak Publications.

Malhotra, V. K. (1993). International Relations. New Delhi: Anmol Publications.

Ministry of Labor, Employment and Social Security. (2020). Nepal Labor Migration Report 2020. Kathmandu: Government of Nepal.

Rana, K. S., \& Chaterjee, B. (2011). The Role of Embassies. In Economic Diplomacy: India's Experience. CUTS International.

Stares, P. B., Jia, Q., Tocci, N., Jaishankar, D., \& Kortunov, A. (2020). Perspectives on a Changing World Order. Council on Foreign Relations.

Steinbock, D. (2017). The Global Economic Balance of Power is Shifting. World Economic Forum.

Stengel, F. A., \& Baumann, R. (2017). Non-State Actors and Foreign Policy. Oxford Research Encyclopedia of Politics, 2-33.

Times of India. (2012, October 9). Banaras Hindu University, Nepali ministry signs MoU for setting up Nepal Chair. Retrieved from Times of India: https:/timesofindia. indiatimes.com/home/education/news/Banaras-Hindu-University-Nepaliministry-signs-MoU-for-setting-up-Nepal-Chair/articleshow/16731558.cms 